\title{
Terrorism in Northern Nigeria: A Threat to Food Security in Maiduguri
}

\author{
Bosede Awodola, PhD \\ Institute for Peace and Conflict Resolution, Abuja \\ boseaw02003@yahoo.com
}

Agyeno Oboshi

Institute for Peace and Conflict Resolution, Abuja

Jacobya007@yahoo.com

\section{Doi:10.5901/mjss.2015.v6n3s2p11}

\begin{abstract}
Food security in Maiduguri has come under threats since the emergence of series of attacks by a terrorist sect called 'Boko Haram' (BH). This paper examined the various ways in which the activities of BH have threatened food security in Maiduguri, the capital of Borno State in the north east of Nigeria. The study was conducted through a field research that involved administration of questionnaire, interviews, observation and elicitation. The data analysis revealed that the $\mathrm{BH}$ actions have affected the agricultural sector. Recommendations were made to ease the chain of food supply.
\end{abstract}

Keywords: Food Security, Boko Haram, Terrorism, Maiduguri, Agriculture.

\section{Introduction}

Terrorism in Nigeria is considered a dangerous phenomenon believed to be contrary to the values and norms of the Nigerian society. The use of force and violence against the people and the destruction of properties with the intention to coerce or terrorize the society is a clear violation of criminal laws and demean moral values. Since the uprising of an Islamic terrorist's sect called the Boko Haram (BH), began in 2002, by Mohammed Yusuf, their activities have been collectively and strongly condemned in Nigeria and by the international community for the mindless and heinous attacks on innocent citizen which have left many dead, traumatized and many properties destroyed. As reported by Leadership Newspaper, (26 th February, 2014), more than three hundred people including innocent students were killed in the month of February 2014 alone, while the entire Federal Government College (FGC), Buni-Yadi in Gujba local government area of Yobe state was razed down by the blood hounds $\mathrm{BH}$; who now attack soft targets in remote villages and schools. The recent dimension of abduction of women and school girls has made the activities of the sect more complicated with many implications.

The $\mathrm{BH}$ has its origin in Maiduguri, the Borno State capital located in the north eastern part of Nigeria. Since the emergence of the $\mathrm{BH}$ activities in Maiduguri, every sector that has direct impact on the well being of the people has been negatively affected, be it political, socio-economic and security. The security impact is multidimensional: while most literature seems to focus solely on physical security, that is, the security of life and property, little attention is paid to the implication of the $\mathrm{BH}$ activities on food security in Maiduguri. It is necessary to focus attention to this dimension because food insecurity does not only constitute a conflict in itself, but it has tendency to exacerbate other conflicts and compound poverty.

Food security was defined at the World Food Summit of 1996 as "when all people at all times, have physical and economic access to sufficient, safe and nutritious food to meet their dietary needs and food preference for an active and healthy life" (FAO, 1996). This definition combines stability, accessibility and availability. Within this study, food security is conceptualize to include opportunity to cultivate food items, accessibility of food to the people at any given time and affordability, to purchase food needed for ones well-being. Food and Agricultural Organisation (FAO), opine that food security can be achieved by ensuring adequate food supply in terms of quantity, quality and variety of food; optimize stability inflow of supplies and secure sustainable access to availability by those who need them (Food Security Policy Brief, 2006). But circumstances such as natural disaster, conflict and terrorist activities may hinder the achievement of sustainable access and availability of food in any environment.

Thus, the purpose of this paper is to examine the activities of $\mathrm{BH}$, an Islamic terrorist sect in Maiduguri and their 
impact on food supplies network include cultivations, availability, accessibility and affordability of food products with a view to determining the threats posed by $\mathrm{BH}$ activities to food security in Maiduguri. In this regard, the important questions are: How does $\mathrm{BH}$ activity pose a threat to food production in Maiduguri? Has $\mathrm{BH}$ actions affected availability of food products? What are the impacts of $\mathrm{BH}$ on accessibility and affordability of food product in Maiduguri? These questions and the answers to them would help to determine the extent to which $\mathrm{BH}$ activities is a threat to food security.

Towards this end, the paper is examined along seven parts, including the methodology used to derive data for this paper, the strategic position of agricultural products in the economy of the area, and the background to $\mathrm{BH}$ insurgences in the township. The fourth section is devoted to data analysis, while the fifth section focused on the limitation of the study. The six section deals with recommendation and conclusion of the study in the final parts.

\section{Methodology}

The study area of this paper is limited to Maiduguri, the capital of Borno State and against the backdrop of the $\mathrm{BH}$ insurgency in the town. Apart from the fact the sect has its origin in Maiduguri, majority of its members and followers reside in the town, with a strong suspicion of foreign membership from neighboring countries of Chad, Niger and Cameroon. The members are alleged to be involved in the gruesome killings, abduction and bombings in Maiduguri. In a nut shell, Maiduguri appears to be the strong hold and spiritual centre of the $\mathrm{BH}$ sect. The sect activities was known as early as in 2002, but assumed a dangerous dimension thereafter. However, this study is concerned with the period when the sect gained notoriety for killings and bombings, that is from, July, 2009 to December, 2013.

The data for this paper was based on the fieldwork carried out in Maiduguri, the capital of Borno State in segments from $3^{\text {rd }}$ March, 2012 - $6^{\text {th }}$ December 2013, through our research assistant who is well acquainted with the state. He served as our informant and through him we were able to identify and establish contacts with other people. The methodology used to gather information included in-depth interviews with stakeholders such as the security agents, university lecturers, farmers, petty trader/artisans, government officials as well as religious leaders. A total number of 53 people were interviewed. Most of the interviews were conducted in confidential manner and as the time of writing this article, the security challenges and threats are still prevalent in the town.

All interviews were recorded on audio-tapes and later transcribed for purpose of data analysis. The article was also complemented by field notes taken at the time of interviews. The elite interviewed spoke at the intellectual level and with strong conviction about the threats of $\mathrm{BH}$ activities in respect to food security in the state, while farmers and petty trader/artisans even though they could not effectively communicate in English language, they however understood the security challenges posed by $\mathrm{BH}$ sect with regards to the same issue.

Also, with the help of our research assistant, 400 survey questionnaires were administered to the people who were randomly selected in the town. Only 222 questionnaires were returned and analyzed to generate data for this paper. Though, the fieldwork covered a period of 20 months, the researcher had to leave the state at interval during the time the federal government declared the state of emergency in order to deal with the precarious security challenges. He later went back to complete the work. These methods were complemented by observation and secondary information sourced from news, journals and internet materials.

\section{Maiduguri and Emergence of Boko Haram}

Maiduguri, the capital city of Borno state in the north-eastern Nigeria is an ancient city, founded in 1907, as a military outpost by the British. It has an estimated population of 1, 197,497 as at 2007 (Profile on Maiduguri, 2007). The inhabitant includes different ethnic groups, including Bura, Fulani, Kanuri, Marghi, and the Shuwa, mostly Muslim but with considerable Christian population. The capital city is also referred to as Yerwa by its locals consists of two towns: Yerwa to the west and old Maiduguri to the east. It sits along the seasonal Ngadda River which disappears into the Firki Swamps in the areas around Lake Chad. The region was home to the Kanem-Borno Empire for centuries and is the principal trading hub for north eastern Nigeria (Ibid). The economy is largely agrarian, where $80 \%$ of the people depend on agriculture for their livelihood, growing both food and cash crops (Tourism and Investment in Borno State, 2011). Some of the major crops include soyabeans, cotton, groundnuts, rice, sesame, cashew, cassava, sweet potatoes, maize, wheat, guinea corn, millet, mangoes, gum Arabic, oranges, water melon, and vegetable including tomatoes, pepper and onions. The state is also prominent for fishing and has great potentials for animal husbandry given the large herds of cattle, sheep/goats and poultry that abound in its environment (Becam Business Environment Report, 2007).

Maiduguri, like other parts of Nigeria, enjoys religious leverage of establishing schools for the advancement of religious teachings especially among the two major religions in Nigeria that is, Christianity and Islam. As in other parts of 
Northern States, an Islamic school to help in the propagation of Islam through the institution of Almajiri system is a common feature in Maiduguri. The Almajiri system is an Islamic educational institution that allows a large number of the people, especially children at very tender age, to have Quranic education under the tutelage of an Islamic teacher or cleric. Over time, this system has been abused by some Islamic clerics who used the avenue to indoctrinate the young ones into religious extremism. A typical outcome of such indoctrination is the establishment of an Islamic sect in Maiduguri called the Jama'atul Ahl-Sunnati Lil Dawa'ati wal Jihad, translated as Boko Haram (Western education is forbidden)

There has been a controversy as to the exact date BH emerged. Nonetheless, there is a common consensus that BH was founded in 2002 by a charismatic 32-year old Ustaz Mohammed Yusuf at Markas mosque in Markas Abba Ganaram road in Maiduguri. The ideology of the sect is anchored on a rejection of western education and influence which they assume is corrupting the way Islam is being practiced. According to Abdul Qaqa, a leading member of the sect "we had a grand plan to Islamize Nigeria starting with the north; we felt that a lot of Muslims are not practicing the religion faithfully as they should" (Ikenna Emewu, 2012). However, (Isa Umar Gusau, 2009; James Forest, 2012) point out that the membership of the sect is not limited to the students of the Quranic School that is established by Mohammed Yusuf, but it includes students who dropped out of the University of Maiduguri as well as disaffected young people and unemployed graduates with deep seated grudges over the socio-economic and political conditions of the country including poor governance and corruption. Madike Isioma (2011) reported that before the demise of Yusuf Mohammed, he had over 500,000 followers.

The death of Mohammed Yusuf which many attributed to extra judicial killing had several implications for the different shades of opinion. Firstly, his death decentralized the leadership of the sect in to different factions. The circumstances of his death led to different views of its members and consequently a more radical approach including the use of violence and terror to prosecute their cause. In the same manner, his death encouraged greater sympathy from members of the public to its ideology. It was this sympathy, which had earlier shrouded its identity that gave rise to the fear of followers not to divulge any information about the sect, thus complicating the security situation that has affected every sector of society in Maiduguri metropolis.

\section{Boko Haram and Challenges to Food Security in Maiduguri}

Maiduguri is a commercial centre that attracted people of other states and nationals. It is a strategic location, along the famous trans-Sahara trade route that place it in a advantaged position in the area of inter-state and international trade, and as a commercial centre, it acts both as a shipment port and a leading commercial centre of the border region (Profile on Maiduguri, 2007). The agricultural product grown and produced in the 27 local government areas in Borno state are brought in to Maiduguri and traded among the three major markets of the Baga fish market, Gomboru market and the Monday market.

Gomboru market, located within the capital city, is located between the major roads that leads to the Gomboru/Ngala border town to Cameroon and Chad. The market is known for its cheap perishable products that attract the masses; just as it serves as a depot for products like groundnut oil and animal skins which are being exported to Chad, Cameroon, Central African Republic (CAR) and Libya. The Baga fish market is situated along Baga road in Maiduguri that leads to Lake Chad Basin. The market is the hub of activities for fish businesses within and outside Nigeria to the republics of Cameroon, CAR and Niger. The Monday market attracts both elites and the masses. It is strategically located to connect the ancient part of Maiduguri with the modern area of the township: the market serves as a vital chain for food distribution and supply in and outside Nigeria. Owing to several attacks in these markets by members of $\mathrm{BH}$, the economic activities have declined in the city and over 30 people were reportedly killed in February, 2012 (Vangurd, 20 May, 2012). The Chairman of the Borno State Marketers Association stated that "There is no business and market in Maiduguri and in Borno state has collapsed completely; the security situation has collapsed the once-booming economic activities in the state. Foreign business men and women from Cameroon, Chad and Niger Republic have also deserted our businesses"(Abubakar Ibn Umar Garbar, 2012). As observe, across the city, many corner shops, business centers and other outfits have shut down (Ali Baba Inuwa 2012).

Similarly, the general public is of the view that the impact on agricultural sector is more severe. The respondents to the survey questionnaire were asked which sector in Maiduguri is most affected since the emergence of $\mathrm{BH}$. Over $56.3 \%$ said the agricultural sectors was most affected, while $12.6 \%$ claimed education sector and $4 . \%$ believed it is government, security $8.6 \%$, religion $9.9 \%$ and economy takes $8.6 \%$ each (see table 1 ). This data indicated that greater percentage of the respondents share the view that security challenges due to terrorist actions constitute high threats to the agricultural sector with greater negative impact on food production and businesses. 
Table 1: Respondents view of the security challenges in Maiduguri

\begin{tabular}{|c|c|c|}
\hline Respondents & Fq. & $\%$ \\
\hline Security sector & 19 & 8.6 \\
Educational sector & 28 & 12.6 \\
Agricultural sector & 125 & 56.3 \\
Government sector & 9 & 4 \\
Religion sector & 22 & 9.9 \\
Economic sector & 19 & 8.6 \\
\hline Total & 222 & 100 \\
\hline
\end{tabular}

Question: Which sector is most affected in the wake of $\mathrm{BH}$ insurgencies?

Source: Authors fieldwork (2013).

Faiza Mohammed (2012), a lecturer at the University of Maiduguri described the threats to agricultural sector as "disturbing". He argued that the industry is experiencing low productivity as many farmers have abandoned their farms for fear of attack on their farm lands, which may translate to low yield. Aliyu Mampawa (2012), another lecturer admitted that this development is further compounded by what he referred to as "farmers drain". He explained that many youths from rural areas that use to tend the farm lands have migrated to Maiduguri to join the 'Jihad' while other had moved to neighboring states or countries. In both cases, lower yields in agricultural production should be expected, thus affecting availability and accessibility to food. Already fear have been expressed at different levels of government of the possibility of food crisis. For example, the United Nations in February 2012 "expressed fears that the activities of the BH sect would make it difficult for the World Food Programme to source its supply from Nigeria to affected areas in the Sahel region" since Maiduguri is a vital link with regard to food availability and supplies to the Sahel region (Olaolu Olusina, 2012).

From field interviews, we gathered that, BH sect have shifted their terror acts to markets; and Maiduguri being a vital place for food distribution across Nigeria and to the neighboring countries. Yahaya Ibrahim (2012) reported that, BH has found markets as fertile grounds of confrontation with military authorities as revealed by the happenings at the three major markets of Monday Market, Gomboru market and Baga market. The assaults on these markets have negatively affected economic life in the state as well as reduce the number of visitors who normally besiege these markets from neighboring countries of Cameroon, Chad, even CAR and Niger; as more than 20 people were been killed in the series of attacks in Monday market and Baga markets. By implication, availability and accessibility to food products to the people would be considerable affected. Indeed, a trader/farmer in Gomboru market, known for large stock of vegetable and fruits, lamented that the market, known to be the hub for perishable farm products, has been attacked on many occasions. According to Mohammed Abba (2012),

Before, this market you can get many things like vegetable, fruits, meats, and groundnut oil and other things at cheaper rate. Now no market (sales) like before that I can sell 80,000 to retailers and other customers. People are afraid of coming to the market, me too am afraid. This market have been attacked many times, while perishable goods left wasted each time of attack causing many traders into incurring debt. Some of us have abandoned their farm land and migrated to Chad or Niger for fear of attack on farm land. Mohammed and Sanni were found dead on their farm land suspected to be the handiwork of $\mathrm{BH}$.

Likewise, another trader in the market expressed his frustration about the state of insecurity which has restricted the movement of the people. According to him, most of the food items selling in Maiduguri are brought in from other local government areas of the state, transporting these food items into market in Maiduguri has been cumbersome due to fear of attacks from BH and the number of check points on the road (Salisu Kiyari, 2012). In fact, roads that lead to major markets in Maiduguri have been deserted like Baga road that leads to the popular Baga Fish market, Kashim Ibrahim road and custom round about road both of which led to Gomboru market. Few vehicles now ply the road, thus leading to increase in transportation fare and increase in the prices of food items beyond the reach of ordinary consumers. Musa Wikil, (2012), recounted his experience thus:

With 30 baskets of tomatoes and pepper, I go pay 9000 from Biu to Gomboru market, but now I go pay 14000. Everything is cost now and people are complaining. I get plenty customers that comes from Lagos, Ibadan, Ogbomoso and other part of the south, now people fear to come, they fear BH. Amidst fear, you spent so much energy to cultivate crops and bring to sell but you get little in return. 'Kai' (exclamation for sympathy), the problem is affecting the supply and also the purchasing power. The situation is bad. 
One can therefore deduce from these experiences that the hike in transportation would lead to increase in the cost of food items with consequences on the purchasing power. Furthermore, Henk-Jan and Hendrix (2011) noted that rising food prices may contribute to food insecurity and may worsen the threat to human security. Accordingly, Yahi Bukar (2012), a government official in an interview expressed fear of the impending food crisis in Maiduguri, and the turning effect on the cost of movement of produce to the market and the security challenges of the check points mounted by security agents and their effect on free flow of movement. The situation, according to security operatives is seen as the unintended consequences of $\mathrm{BH}$ activities and, as security operators we must do our work and do it thoroughly (John Olawale, 2012). Another government official Komo lyana (2012) presented the situation thus:

\begin{abstract}
Maiduguri is the centre of trade in the north east of the country. The markets in Maiduguri serve as a centre point in which food of all kinds is being exported to other areas. Now you can imagine what happen to these areas when the state itself could not provide enough. It is obvious that supplies of food become a problem and when you get it you cannot afford to pay for it due to increase in price, what is the essence then? $80 \%$ of the people of the state are farmers and the state is surely loosing a lot which I cannot quantify in monetary terms
\end{abstract}

To further confirm the increases in the cost of food items, our survey respondents were asked to specify possible implication of $\mathrm{BH}$ activities on agricultural sector. About $34.78 \%$ mentioned increase in prices of staple food, $19.57 \%$ thought food supply, $15.22 \%$ felt getting accesses to food; the remaining $30.43 \%$ mentioned farming of crops/livestock (see table 2). In this case, the people in Maiduguri may not have economic access to provide for themselves the quality of food needed for a healthy life. The availability of food which is strongly connected to cultivation of crops as well as breeding of live stocks has considerably decline due to activities of $\mathrm{BH}$, creating a situation of food scarcity: which an Islamic cleric considered an offence against the teaching of the Holy Quaran. Abdulkadir Mihammed (2012) stated that no man should deprive another being their means of livelihood including the satisfaction of hunger. A public servant in Maiduguri presented the condition of living as pathetic; he retorted that "what is keeping the people together is the spirit of brotherhood as some people now go on credit for food supplies and items" ( Babagana Isa, 2013).

Table 2: Respondents view on implication of $\mathrm{BH}$ on food security

\begin{tabular}{|c|c|c|}
\hline Respondents & Fq. & $\%$ \\
\hline Prices of food items & 77 & 34.7 \\
\hline Food supply & 43 & 19.3 \\
\hline Access to food & 33 & 14.9 \\
\hline Farming of crops/livestock & 69 & 31.1 \\
\hline Total & 222 & 100 \\
\hline
\end{tabular}

Question: How does BH affect the agricultural sector?

Source: Authors fieldwork (2013).

To confirm the high cost of food items in Maiduguri, we visited the three major markets in the town to ascertain the increase in the cost of food items and to observe transactions in the market. The obvious thing that caught our attention in each of these markets was the physical destruction in parts of these markets due to $\mathrm{BH}$ attacks. Respondents at the Baga market stated that the incessant attack and closure of the market at various time has also contributed to the decline in profit margins of sellers ( Hassan Maigari, 2012; Nwani Betara, 2012). Sometimes, food stores are locked and goods are perished as farmers, food sellers and transporters are scared or running away to avoid being casualties (Ibrahim Abdul'Aziz, 2012). Put differently, traders are barely in business as the level of sales remains poor (Umar Mamza, 2012). Table 3 shows the food items available in the markets that we visited and made some comparism of the cost of food items before the insurgencies and what the prices as at December, 2013. 
Table 3. Table indicating differences in food prices and percentage of increment

\begin{tabular}{|c|c|c|c|c|c|}
\hline S/N & Food Items & Quantity & Previous Price & Current Price & Increase in Percentage (\%) \\
\hline 1. & Millet & Per bag & 5,000 & 9,000 & 80 \\
\hline 2. & Maize & Per bag & 5,000 & 7,500 & 50 \\
\hline 3. & Wheat & Per bag & 12,000 & 16,000 & 33.33 \\
\hline 4. & Soya beans & Per bag & 10,000 & 13,000 & 30 \\
\hline 5. & Irish Potatoes & Per basket & 5,000 & $7000-8000$ & 50 \\
\hline 6. & Fish & Per carton/basket & 21,000 & $27,000-30,000$ & 35.71 \\
\hline 7. & Cattle & Per one & 45,000 & $80,000-12,000$ & 122.22 \\
\hline 8. & Goat & Per one & 6,000 & $8,500-10,000$ & 54.16 \\
\hline 9. & Red Beans & Per bag & 20,000 & 25,000 & 25 \\
\hline 10 & White Beans & Per bag & 18,000 & $20,000-21,000$ & 13.89 \\
\hline 11. & Sweet potatoes & Per basket & 3,400 & $4,000-5,000$ & 32.35 \\
\hline 12. & Tomatoes & Per basket & 3,300 & 6,000 & 160 \\
\hline 13. & Pepper & Per basket & 5,000 & 13,000 & 25 \\
\hline 14. & Onions & Per basket & 4,000 & 5,000 & 43.75 \\
\hline 15. & Water Melon & Per one & 800 & 1,150 & 11.76 \\
\hline 16. & Groundnut oil & Per galloon & 8,500 & 9,500 & 31.25 \\
\hline 17. & Orange & Per bag & 8,000 & 10,500 & \\
\hline
\end{tabular}

Source: Authors fieldwork (2013).

\section{Findings}

From the analysis, the study clearly revealed the possibility of food crisis in Maiduguri as the activities of the $\mathrm{BH}$ intensifies. The study shows that the cultivation of crops, a critical aspect of food security, is gravely under threat given low cultivation of crops as a result of $\mathrm{BH}$ atrocities (see table 1). This fact has also affects availability/supply, accessibility and affordability of food items in the area. As indicated by respondents, supplies of food are increasingly hampered by many road blocks put in place by security personnel as well as hike in prices of transport and risk of transporting farm products to the markets in Maiduguri. The study shows that the hike in transportation of farm produce has affected the prices of food items considerably (see table 2 and 3 ) and affects the purchasing power of the people. Put differently, the people in Maiduguri may no longer be able to afford the minimum dietary energy requirement and satisfying their hunger may also be jeopardized with consequences for social security. Indeed, the study revealed that most shops were under lock in the three major markets in Maiduguri, which is an indication of the destruction of most agro businesses.

\section{Limitation of the Study}

Threats to food Security is not limited to Maiduguri Township alone, because the terror unleashed by BH has affected every part of the state. However, the study is only concerned with Maiduguri being the location of the origin of $\mathrm{BH}$ and its strategic location of food supplies to other parts of Nigeria as well as neighboring countries. More so, accessing other part of Borno State was difficult due to prevailing security situation posed by BH. The study was also limited by the number of contacts for interviews and respondents to survey questionnaire due to fear by the people to discuss issues relating to $\mathrm{BH}$

The impact of $\mathrm{BH}$ is felt in all sectors of Maiduguri; however, since larger percentage of the socio-economic activities of the people is directly or indirectly connected to agriculture, a sector that serves the most basic need of the people. Consequently, the study is limited to the impact of $\mathrm{BH}$ on food security in Maiduguri and dwell on the physical aspect of food production, supply, accessibility and affordability. We are not ignorant of the minimum dietary energy requirement which may involve the nutritional aspect of food security.

\section{Conclusion}

The study examined the impact of $\mathrm{BH}$, a terrorist sect on the threat to food security in Maiduguri. Data analysis established likely threat to food security in Maiduguri and beyond due to activities of $\mathrm{BH}$. To this end, effort by the government of Nigeria, and indeed the international community, in curbing the menace of $\mathrm{BH}$ would be a welcome development. It is expected that the state government and other stakeholders including non-governmental organization 
should provide opportunity for the young unemployed youth to be engaged in meaningful work so as to prevent them from being instrument of violence. Governments should, as a short time-measure, demand and distribute food from the national reserve in order to reduce the hardship being experienced by the people.

\section{References}

Abdulkadir Mohammed, personal interview, 10 April, 2012, Maiduguri, Nigeria

Abubakar Ibn Umar Garbai El-Kanemi, (2012) "Economic Activities have been paralyzed in Maiduguri" Blueprint, 16 March.

Ali Baba Inuwa, (2012) "Boko Haram and Borno State Economy" The Tide, 22 August.

Aliyu Mampawa, personal interview, 16 March, 2012, Maidugiri, Nigeria.

Babagana Isa, personal interview, 11 April 2012, Maiduguri, Nigeria.

BECAM Business Environment Report, Borno State, (2007) African Institute for Applied Economic. Vol. 1 Number 9.

Faiza Mohammed, personal interview, 16 March, 2012, Maiduguri, Nigeria

FAO, (1996) World Food Summit - Rome Declaration on World Food Security and WFS Plan of Action. WFS Document. Rome, FAO.

Food Security, "Policy Brief" (2006) Issue 2, June. ftp://ftp.fao.org/es/esa/policybriefs/pb_02.pdf. (Accessed 25 July 2012).

Hassan Maigari, personal interview, 10 April 2012, Maidiguri, Nigeria.

Henk-Jan Brinkman and Cullen S. Hendrix, (2011). "Food Security and Violent Conflict: Causes, Consequences, and Addressing the Challenges. World Food Programme. Occasional Paper no.24, July

Ikenna Emewu 'Abu Quqa Kabiru Sokoto Open Up' NBF News, 8 March 2012.

Isa Umar Gusau, (2009) "Boko Haram: How It All Began" Daily Trust, 2 August.

James J.F. Forest, (2012) "Confronting the Terrorism of Boko Haram in Nigeria." Joint Special Operations University Report 12-5, May. John Olawale, personal interview, 11 April 2012, Maiduguri, Nigeria.

Komo lyana, personal interview, 12 April 2012, Maiduguri, Nigeria

Leadership Newspaper (2014) "How Gun Men Killed 43 Students in Yobe" 26"th February

Madike Isioma, (2011) "Boko Haram: Rise of a Deadly Sect", National Mirror, 19 June.

Mohammed Abba, personal interview, 18 March 2012, Maiduguri, Nigeria.

Musa Wikil, personal interview, 19 March 2012, Maiduguri, Nigeria.

Nwani Betara, personal interview, 10 April, Maiduguri, Nigeria.

Olaolu Olusina, (2012) "The Imminent Food Crisis" Thisday, 8 July.

Profile of Maiduguri, on http://en.wikipedia.org/wiki/Maiduguri. (Accessed on 28 June 2012).

Salisu Kiyari, personal interview, 18 March 2012, Maiduguri, Nigeria.

Tourism and Investment Opportunities in Borno State. Volume 2 on http://www.BS_Tourism_and_Investment_Opportunities.pdf-Adobe . (Accessed on 27 June 2012).

Umar Mamza, personal interview, 10 April 2012, Maiduguri, Nigeria.

Vangaurd (2012) "Women, Children Killed as Boko Haram Attacked Market" 20 May.

Yahaya Ibrahim, (2012) "Maiduguri: Markets now Targeted for Attack by Boko Haram" Sunday Trust, 26 February.

Yahi Bukar, personal interview, 11 April 2012, Maiduguri, Nigeria. 